Clairvoyant of the Small 


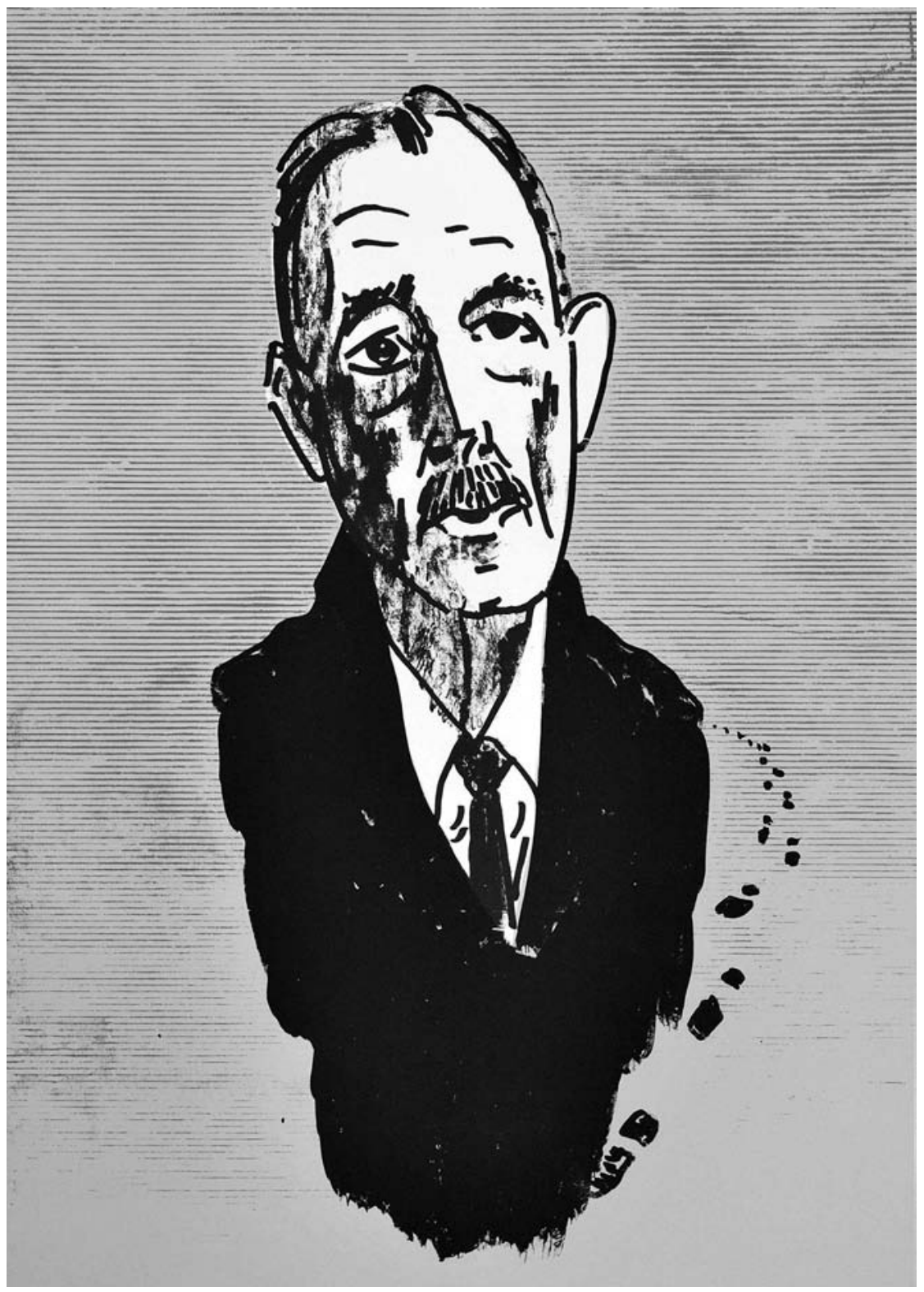




\section{Clairvoyant of the Small}

\section{The Life of Robert Walser}

\section{Susan Bernofsky}


Published with assistance from the foundation established in memory of Philip Hamilton McMillan of the Class of 1894, Yale College.

\section{Copyright (C) 2021 by Susan Bernofsky.}

All rights reserved.

This book may not be reproduced, in whole or in part, including illustrations, in any form (beyond that copying permitted by Sections 107 and 108 of the U.S. Copyright Law and except by reviewers for the public press), without written permission from the publishers.

Yale University Press books may be purchased in quantity for educational, business, or promotional use. For information, please e-mail sales.press@yale.edu (U.S. office) or sales@yaleup.co.uk (U.K. office).

Set in Bulmer type by IDS Infotech Ltd.

Printed in the United States of America.

Library of Congress Control Number: 2020948375

ISBN 978-0-300-22064-3 (hardcover : alk. paper)

Frontispiece: Klaus Dennhardt, Portrait of Robert Walser

(Private Collection of J. A. Hopkin, Berlin)

A catalogue record for this book is available from the British Library.

This paper meets the requirements of ANSI/NISO Z39.48-1992 (Permanence of Paper).

10987765543221 
For Richard 
This page intentionally left blank 